\title{
DOS SENHORES AOS INQUISIDORES: ESCRAVOS AFRICANOS SOB O PODER DO SANTO OFÍCIO NO MUNDO LUSO-BRASILEIRO (SÉCULOS XVII E XVIII)
}

\section{FROM MASTERS TO INQUISITORS: AFRICAN SLAVES UNDER THE POWER OF THE HOLY OFFICE IN THE BRAZILIAN LUSO WORLD (XVII AND XVIII CENTURIES)}

Monique Marques Nogueira Lima36

Resumo: O objetivo deste artigo é o de analisar o poder do Santo Ofício, como instituição religiosa, sobre os escravos africanos que, compulsoriamente, foram levados da África ao reino ou à colônia lusa da América. Com o olhar voltado, especialmente, à compreensão de algumas premissas importantes, como o batismo e a instrução na Fé, o intuito foi o de apresentar as polêmicas teológico-jurídicas da época sobre a conversão para, assim, entender o lugar da Inquisição e sua atuação sobre aqueles que eram considerados, muitas vezes, gentios e ignorantes. A partir da perspectiva de análise que frisa a relação senhorescravo, três pontos centrais foram analisados: a conversão dos africanos e, portanto, a importância do batismo e da instrução na Fé; o olhar do Santo Ofício acerca dos gentios, evidenciado a partir do Conselho Geral ou de sua prática; por fim, o arbítrio e poder dos senhores e inquisidores sobre a vida dos escravos.

Palavras-chave: Escravos. Gentios. Inquisição. Relação senhor-escravo. Batismo e instrução na Fé.

\begin{abstract}
The purpose of this article is to analyze the power of the Holy Office, as a religious institution, about the African slaves who, compulsorily, were taken from Africa to the kingdom or to the Portuguese colony of America. With a particular focus on the understanding of some important premises, such as baptism and instruction in the Faith, the purpose was to present the theological-juridical controversies of the time about conversion, in order to understand the place of the Holy Office and his performance over those who were often considered to be Gentiles and ignorant. From the perspective of analysis that emphasizes the master-slave relationship, three central points were analyzed: the conversion of Africans and, therefore, the importance of baptism and instruction in the Faith; the Holy Office's understanding of the debate, as evidenced by the General Council or its practice; and finally, the will and power of the lords and inquisitors over the life of the slaves.
\end{abstract}

Key-words: Slaves. Gentiles. Holly Office. Masters and slaves. Baptism and instruction in the Faith.

${ }^{36}$ Doutoranda do Programa de Pós-Graduação da Universidade Estadual Paulista, "Júlio de Mesquita Filho", campus de Franca, SP - Brasil. Membro do Grupo de Pesquisa "Escritos sobre os novos mundos: uma história da construção de valores morais em língua portuguesa". Agradeço ao apoio da FAPESP (processo número 2017/04244-2) e da CAPES. E-mail: moniquemarqueslima@outlook.com. REHR | Dourados, MS | v. 13 | n. 25 | p. 55-75 | Jan. / Jun. 2019 


\section{HISTÓRIA \\ MUNDO LUSO BRASILEIRO: RELAÇÕES DE PODER E RELIGIÃO}

\section{Introdução}

$\mathrm{Na}$ baila da expansão portuguesa sobre novos territórios, esta também empreendida com o objetivo, imbuído ao projeto imperial, de resgate das almas, chegaram aos ouvidos de diferentes homens do reino a existência de povos que não conheciam os mistérios e coisas da verdadeira Fé (THORTON, 2004). As entradas portuguesas em África, iniciadas em Ceuta, no ano de 1415, não prescindiram dos discursos religiosos em diferentes momentos e vertentes. De um lado, o anseio pela salvação dos infiéis foi, antes, retórica de incentivo na pena daqueles que apoiavam o projeto expansionista; ${ }^{37}$ de outro, a interiorização e maior contato com os povos africanos, não apenas do Norte, fizeram urgir, de igual forma, a necessidade de missionação e, uma vez mais, do controle e vigilância da consciência de seres que, uma vez introduzidos na Fé Católica, deviam responder ao regulamento de sua moral.

Com a chegada em terras subsaarianas, denominadas, então, genericamente de Guiné, o deslumbre inicial referente ao que relataram, não poucas vezes, como um novo tipo de humanidade encontrada (HORTA, 1991), passou, depois da conversão inicial, à necessidade da correta instrução e repressão das dissidências em relação às práticas, costumes e crenças. Tal povo, que foi, em grande proporção, escravizado sob a alegação dupla de que sua ascendência era amaldiçoada e que, por conseguinte, o cativeiro configurava uma importante via para sua salvação (ALMEIDA, 2018), esteve, em diferentes lugares do Império português, sob o jugo e arbítrio do Santo Ofício. Era este tipo de diligência espiritual, por exemplo, que parecia empreender Frei Lourenço de Lucia, comissário da Inquisição, para Luanda, quando expunha o estado da causa no conteúdo de uma correspondência de 1716:

para que conheçam o muito cuidado que tenho de manter florescido a Nossa Santa Fé nestas partes tão remotas da Nossa África, e como comissário também do Santo Ofício, muito mais obrigado me reconheço a notificar todas as desordens, [...] pois se estes feiticeiros

\footnotetext{
$37 \mathrm{O}$ mais famoso texto que demonstra o posicionamento da Coroa portuguesa e a ideia geral acerca do domínio sobre os territórios da África negra e o controle dos seus povos é a "Crónica do descobrimento e conquista da Guiné" (ZURARA, 1937).
}

REHR | Dourados, MS | v. 13 | n. 25 | p. 55-75 | Jan. / Jun. 2019 


\section{HISTÓRIA \\ MUNDO LUSO BRASILEIRO: RELAÇÕES DE PODER E RELIGIÃO}

se multiplicam podem perverter todo este povo (AN/TT ${ }^{38}$, TSO, IL, Cadernos do Promotor, n. 86, livro 279, f. 39).

A vigilância e repressão das transgressões dos africanos por parte da justiça responsável pelos erros pertinazes de Fé, no entanto, não se restringiram àqueles assistentes em África, mas, ao contrário, estendeu-se, ainda com maior força, sobre os que, compulsoriamente, foram levados aos diferentes domínios da Coroa portuguesa. Com efeito, a atuação do Santo Ofício no território africano, comparativamente diminuta em relação aos demais territórios portugueses (Goa com a instalação de um tribunal - e a colônia brasileira, por exemplo), ainda parece ser tema carente de mais estudos. ${ }^{39}$ De qualquer forma, a ação sobre essa população, que foi espalhada com o impulso do tráfico transatlântico, pode ser mais bem observada no reino ou na colônia lusa da América. Variados $\operatorname{casos}^{40}$, que envolvem, majoritariamente, por um lado, acusações de práticas consideradas feitiçarias e, por outro, costumes que se ligam aos desvios da carne, como a sodomia e a bigamia, além de acusações de islamismo, podem ser objetos de estudo para o entendimento de como a Inquisição, tão preocupada com a heresia dos judaizantes, recebeu sob a sua competência, também, os erros de homens e mulheres que, amiúde, poderiam ser entendidos como rudes e ignorantes.

Neste texto, o intuito é o de lançar um olhar sobre algumas questões que, por configurarem premissas presentes nos discursos teológicos da época, estiveram, também, nas pautas e prerrogativas de atuação do Santo Ofício sobre os africanos, como a condição dos escravizados e a inserção de suas vidas na doutrina católica. Além disso, é objetivo, igualmente, apresentar alguns aspectos dos processos criminais da justiça inquisitorial contra escravos, residentes nos diferentes lugares da colônia brasileira e do reino, entre os séculos XVII e XVIII, que passaram à

\footnotetext{
${ }^{38}$ É opção, neste trabalho, seguir o uso da abreviatura AN/TT para designar o Arquivo Nacional da Torre do Tombo.

39 É possível mencionar os seguintes trabalhos: HORTA, José. A Inquisição em Angola e Congo: o inquérito de 1596-98 e o papel mediador das justiças locais. História e Crítica. Lisboa, vol.2, 1988. SILVA, Filipa Ribeiro da. A Inquisição em Cabo Verde e S. Tomé e Príncipe (1536 a 1821): contributo para o estudo da política do Santo Ofício nos territórios africanos. (Dissertação de mestrado). Faculdade de Ciências Sociais e Humanas da Universidade Nova de Lisboa, 2002.

${ }^{40} \mathrm{Em}$ pesquisa, Didier Lahon localizou cerca de 300 processos que envolviam homens e mulheres pretos e mulatos no reino; quanto à colônia, o número gira em torno de 150 processos (LAHON, 2004). Em relação ao Tribunal de Lisboa, Ana Margarida Pereira apresenta o número de 140 processos relativos à população de origem africana no período compreendido entre 1671 e 1790 (PEREIRA, 2014).
}

REHR | Dourados, MS | v. 13 | n. 25 | p. 55-75 | Jan. / Jun. 2019 


\section{HISTOORIA \\ MUNDO LUSO BRASILEIRO: RELAÇÕES DE PODER E RELIGIÃO}

competência do Santo Ofício, demonstrando os problemas que giravam em torno da relação senhor-escravo e, de igual modo, das questões sobre como este Tribunal entendeu as práticas, rituais e costumes, da população africana. A ideia é a de apresentar aspectos da problemática sobre a conversão e instrução de escravos, com o olhar, posterior, sobre as suas vivências, já que, uma vez subjugados ao poder dos seus senhores, esses passaram à dominação de outro tipo de poder, agora imposto sobre suas consciências (PROSPERI, 2013). Em conjunto, foi importante a análise sobre diferentes fontes, tratados e manuais, que apontassem a obrigação senhorial sobre o destino e a alma dos seus cativos. Essas vidas, assim, conhecidas pois atravessadas por um poder que mais não quis que vasculhar aquilo que tinham de mais íntimo (FOUCAULT, 2018), são, aqui, tratadas individualmente. Antes, de qualquer forma, tais premissas foram exploradas.

Batizar, instruir e corrigir: algumas premissas

Se a condição de escravo, discutida no cerne das novas conquistas, foi justificada pela perspectiva da conversão, tal como instituído nas bulas papais do século XV, Dum Diversas (1452) e Romanus Pontifex (1455) (SAUNDERS, 1994), isso significava, a partir do discurso teológico, que existia a necessidade de inserção dos cativos aos sacramentos e à doutrina da Igreja, mesmo que isso se realizasse de maneira forçada. ${ }^{41} \mathrm{O}$ batismo se tornou, então, porta de entrada dos gentios na religião e, ao mesmo tempo, o primeiro ritual católico que viabilizava a escravidão. $O$ caminho do cativeiro, que se transformou em martírio para a salvação, devia acompanhar a assistência por parte dos religiosos e da Igreja. Mais que isso, os senhores, detentores, a partir de então, de vidas boçais e novas em Cristo, eram responsabilizados, também, pela salvação de suas almas. Batizar e instruir na fé constituíram prerrogativas importantes, tanto para a legitimação da propriedade dos escravos quanto para a possibilidade de correção dos seus erros.

41 O historiador Giuseppe Marcocci discute a questão da consciência de um Império, demonstrando como, em meio a discussão da legitimação da escravidão, o argumento do batismo dos gentios se transformou para a viabilização da escravidão. Entende, ainda, como a experiência com a conversão forçada dos judeus criou um modelo que também foi usado no caso dos índios e negros africanos (MARCOCCl, 2012).

REHR | Dourados, MS | v. 13 | n. 25 | p. 55-75 | Jan. / Jun. 2019 


\section{HISTÓRIA \\ MUNDO LUSO BRASILEIRO: RELAÇÕES DE PODER E RELIGIÃO}

Em 1603, quando da promulgação do primeiro código de leis sob a Coroa dos Áustrias, ou seja, durante o período de união e domínio dos Filipes, a obrigação, que já se apresentava no código congênere anterior ${ }^{42}$, da época de D. Manuel, fazia-se evidente: "se escravos da Guiné tiver, os faça batizar e fazer cristãos" (Ordenações Filipinas, Livro V, Capítulo 99, p. 308). Aplicar a doutrina, nesse caso, tornou-se um desafio maior, haja vista que, muitas vezes, o ritual do batismo dos gentios, baseado no modelo imposto aos judeus, desde 1497, não exigia a experiência de uma catequização anterior e partia de uma iniciativa forçada (MARCOCCl, 2010). A instrução e a doutrinação dos cativos na fé, diferentemente do sacramento inicial, todavia, poderia constituir um problema no cotidiano do cativeiro, agravado quando as práticas comuns aos africanos configuravam uma heresia e/ou constituíam, aos olhos dos senhores, uma ameaça. Para estes, a obrigação imposta parecia clara: mostrar, com o próprio exemplo, o ideal de vida cristã; cuidar da doutrinação dos seus cativos e se responsabilizar pelos seus erros e pecados, ainda que isso significasse obriga-los ao cumprimento do sacramento da confissão ou entrega-los aos poderes de justiça da Igreja.

Padre Manuel Ribeiro Rocha (? - 1778), imbuído da função de indicar aos donos as vias corretas de tratamento dos seus escravos, emprestou de outros teólogos as passagens didáticas para a explicação: "O senhor que tem um servo neófito e não se importa em instruí-lo na doutrina cristã peca mortalmente [...]. E se tem escravos convertidos a fé, hão de lhe ensinar por si, ou por outro, a doutrina cristã e dar-Ihes a entender que coisa é ser cristão e que vida hão de ter" (Manuel Ribeiro Rocha, 2017, p. 150). Tal instrução, ainda, completava-se com o ensinamento minucioso da principal parte da doutrina, "que era o Credo, os mandamentos da lei de Deus e da Santa Madre Igreja, o Padre Nosso e Ave-Maria, os sete pecados mortais e os sete sacramentos" (Manuel Ribeiro Rocha, 2017, p. 151). O grau de conhecimento dessas prerrogativas básicas de um bom cristão, que eram, assim, parte importante para a medida da real instrução, configuravam, por um lado, o incentivo dos senhores em catequizar, ainda mais, seus escravos rudes e

\footnotetext{
42 Já nas Ordenações manuelinas havia a prerrogativa da obrigação, por parte dos senhores, de batizarem seus escravos (Ordenações manuelinas, Livro V, tit. XCIX, p. 300).
}

REHR | Dourados, MS | v. 13 | n. 25 | p. 55-75 | Jan. / Jun. 2019 


\section{HISTÓRIA \\ MUNDO LUSO BRASILEIRO: RELAÇÕES DE PODER E RELIGIÃO}

boçais, mas, em outros momentos, demonstravam a ignorância desses homens e a ingenuidade dos seus erros.

A gravidade dos erros de fé dos gentios foi, desde cedo, motivo de debate. A consideração sobre a ignorância invencível poderia significar a impossibilidade de perpetração do castigo eterno ou das penas do direito. ${ }^{43}$ Segundo a discussão, que esteve presente no pensamento de diferentes letrados, por exemplo o Padre António Vieira (1608 - 1697), por apresentar uma ignorância intransponível, marcada por uma inteligência tosca, os gentios e selvagens desconheciam a verdadeira Fé e, por isso, não poderiam ser considerados passíveis do mesmo julgamento e penas que os cristãos-velhos, nem serem alvos do mesmo tipo de evangelização. Conforme o inaciano, a salvação demandava a instrução completa dos infiéis convertidos, mas também poderia aceitar uma ação incompleta, porém suficiente, àqueles cuja ignorância configurava um obstáculo invencível. Se viviam em estado de gentilidade, poderiam, ainda que de forma reduzida, salvarem-se pela palavra de Deus. Do mesmo modo que os animais irracionais, estes deviam ganhar "uma certa condição intermédia entre os bem-aventurados e os condenados, decerto que não em estado de felicidade, mas menos infelizes pela sua ignorância, visto que o Salvador infinitamente misericordioso devia salvá-los, tal como os jumentos" (Padre António Vieira, 2015, p. 811).

Dar a instrução possível para coloca-los numa via intermédia de salvação, ao lado dos bem-aventurados, também pareceu resultar na compreensão de que a constatação do conhecimento mínimo da Fé era suficiente para a aplicação das correções e penas. No dia a dia do cativeiro, ao senhor estava dada a tarefa da correção diária, o que significava, em torno do tema da doutrinação, o remédio para a dissimulação acerca da religião ou "para a falta de aplicação e cuidado do escravo em aprender" (Manuel Ribeiro Rocha, 2017, p.154). A proporção da lição devia ser a mesma do castigo. Outros comportamentos, todavia, por ultrapassarem os limites de

\footnotetext{
${ }^{43} \mathrm{O}$ assunto já foi muito bem discutido no caso dos ameríndios da América espanhola e portuguesa, respectivamente: CISNEROS, Gerardo L. Ignorancia invencible? Superstición e idolatria ante el Provisorato de índios y chinos del Arzobispado de México em el siglo XVIII. México: Universidad Nacional Autónoma de México, 2014. RESENDE, Maria L. C. de. Cartografia gentílica: os índios e a Inquisição na América portuguesa (século XVIII). In: FURTADO, Júnia Ferreira; RESENDE, Maria L. C. de. (org.). Travessias inquisitoriais das Minas Gerais aos cárceres do Santo Ofício: diálogos e trânsitos religiosos no Império luso-brasileiro (séculos XVI-XVIII). 1. Ed. Belo Horizonte: Fino Traço, 2013.
} 


\title{
HISTÓRIA \\ MUNDO LUSO BRASILEIRO: RELAÇÕES DE PODER E RELIGIÃO
}

ação senhorial e serem considerados pecados ou mesmo heresias, chegavam aos ouvidos dos confessores, passavam ao domínio da justiça eclesiástica e, na ponta do controle e vigilância dos costumes, podiam chegar à jurisdição da justiça inquisitorial. Se, a depender, os erros dos africanos escravizados poderiam ser considerados frutos do desconhecimento ou da ignorância, em muitos casos, a instrução, ainda que considerada incompleta, poderia ser entendida como suficiente para a constatação das culpas e imputação das penitências e penas.

Ao estimular a concernência sobre o entendimento mais profundo acerca de variados casos, o Conselho Geral do Santo Ofício, órgão central de decisão na hierarquia do Tribunal, apontou o cuidado com os novos convertidos à Fé. Ao ter como objetivo o esclarecimento acerca de alguns casos dos gentios da Índia, o parecer tomava conta, de forma mais geral, de toda a gentilidade. Como adaptação e resposta ao Breve Papal de Clemente VIII (1536 - 1605), que impunha novidades no tratamento dos neófitos ${ }^{44}$, o documento destacava as seguintes premissas:

\begin{abstract}
A piedade da Sé Apostólica a todos pode abranger; e o rigor de direito a respeito de todos se pode temperar. Mas estas razões gerais não se expõem para todos os que nelas se induzem, mas para as pessoas de que na Bula ${ }^{45}$ se trata, que são os convertidos da gentilidade, que largam os erros da infidelidade que seguiam, com água do batismo que tomam, para que orvalhados com ela, crescerem e lançarem maiores raízes firmando-se na Fé que receberam a serem perfeitos filhos da Igreja, e estes são os neófitos batizados em pé e não os batizados na infância [...] porque diz que os neófitos de que se trata que trazem origens de gentios ou infiéis que depois de receberem a Fé caírem no crime de heresia, ou apostasia, ou em outras heresias danas e reprovadas, primeira, segunda e ainda terceira vez, conhecendo ele o verdadeiro arrependimento, abjuram na primeira os seus erros, e se lhes possam remitir as penas de direito, ainda a de relaxação e outras corporais (AN/TT, Conselho Geral do Santo Ofício, livro 272, f. 49).
\end{abstract}

\footnotetext{
44 O mesmo documento do Conselho apresenta o termo "neófitos" com mais de uma possibilidade de significação. De antemão, explica que neófito é quem "se converte de religião conhecida contra a Fé Católica", mas que "estes mesmos, se derem sinais de bons católicos e perseverança na Fé, não obstante serem batizados em pé, não se dizem neófitos" (ANTT, Acerca dos Neófitos, Conselho Geral do Santo Ofício, Livro 272, f. 42). Na generalidade, todavia, conforme o dicionário do Padre Raphael Bluteau, o termo foi especialmente designado aos "novos convertidos à Fé e que se andam catequizando" (BLUTEAU, 1789. p. 113).

45 Refere-se, aqui, na verdade, ao Breve, que foi emitido pelo Papa Clemente VIII, no ano de 1598, relativo aos neófitos.
}

REHR | Dourados, MS | v. 13 | n. 25 | p. 55-75 | Jan. / Jun. 2019 


\section{HISTÓRIA}

\section{MUNDO LUSO BRASILEIRO: RELAÇÕES DE PODER E RELIGIÃO}

Os africanos, quando introduzidos, forçosamente, nas dinâmicas do Império, passaram, também, ao lado dos povos da Índia e dos ameríndios, a serem identificados sob a designação de gentio, termo do ideário católico que indicava, mais do que a qualidade social ou a cor da pele, o estágio cru e vazio de conhecimento das coisas de Deus e do caminho da salvação (PAIVA, 2015). Dado esse entendimento, para o órgão central do Santo Ofício, de acordo com a consideração do parecer, o recebimento dos gentios devia, a partir de então, depender da experiência de vida desses homens enquanto cristãos e da absorção da doutrina. A reincidência nas culpas, ação veemente combatida por um Tribunal criado e direcionado à luta contra o "erro obstinado e pertinaz de Fé" (BETHENCOURT, 2000), poderia ser amenizada e a remissão era prevista apenas aos que eram considerados neófitos, batizados em pé, mas não aos seus descendentes e nem aos batizados na infância, pois esses, já em contato com a religião, deviam ter internalizados os preceitos da fé: "os descendentes, neles não haja o perigo de se perverterem com a doutrina de seus pais por serem católicos e terem mais eficazes meios para conservarem na fé, não se lhe remete a pena [...], pois que o caíssem nos ditos erros mais procede da sua malícia do que da sua rudeza" (AN/TT, Conselho Geral do Santo Ofício, livro 272, f. 50).

O parecer, de qualquer modo, transmitia a ideia de que, apenas no estado mais rude e párvulo, a remissão das culpas se tornava premissa incontornável no momento de acolhimento dos novos convertidos ou decisão sobre seu julgamento. No mais, quando estes demonstravam o conhecimento da religião e, publicamente, davam sinais de bons cristãos, não podiam, pois, serem compreendidos no Tribunal a partir do pressuposto de ignorantes, ou mesmo, nesse sentido, de neófitos (ANTT, Conselho Geral do Santo Ofício, livro 272, f. 42). Tal diretiva, embora partisse da instância máxima de poder dentro da instituição, não pode, necessariamente, exprimir a prática ${ }^{46}$ e o verdadeiro tratamento direcionado aos que foram colocados sob a categoria de gentio - os povos da Índia, os negros africanos e os índios da

\footnotetext{
46 Bruno Feitler explica, em relação aos Regimentos da Inquisição, que há um espaço considerável entre as normas ideais de regulação deste Tribunal e a sua prática processual. Por isso, é preciso pensar que, embora o Conselho Geral tivesse uma atuação importante na decisão de casos particulares e controlasse de perto as ações inquisitoriais, devido à importância de seus membros, inquisidor-geral e deputados, há de se ter um cuidado analítico de pensar que a aplicação de tais regras no dia a dia da práxis dependia de outros fatores, bem como a sua circulação podia ser relativizada nos confins do Império (FEITLER, 2009).
}

REHR | Dourados, MS | v. 13 | n. 25 | p. 55-75 | Jan. / Jun. 2019 


\section{HISTÓRIA \\ MUNDO LUSO BRASILEIRO: RELAÇÕES DE PODER E RELIGIÃO}

América. Uma análise mais pormenorizada dos processos pode apontar outras variantes. Outro olhar, de toda forma, minimizado às duas últimas categorias, marcam uma diferença importante de tratamento que, uma vez inserida no cerne da discussão jurídico-teológica própria dos Impérios lbéricos, não se pode, aqui, desconsiderar.

O tema da conversão e salvação das almas dos gentios remete à um debate antigo, do início do século XVI, que teve lugar principalmente no espaço dos teólogos castelhanos $^{47}$, mas que também esteve presente na pauta das preocupações da Coroa de Portugal e de alguns letrados portugueses incomodados com as questões das próprias consciências. ${ }^{48}$ A questão, entretanto, que marca a comparação entre índios e negros africanos, já que são dois setores tutelados na hierarquia social, é, precisamente, as vozes acionadas em relação aos primeiros e o silêncio em relação aos últimos. ${ }^{49}$ Conforme o historiador Giuseppe Marcocci (2010), não houve, para o Império português e hispânico, nenhuma preocupação mais específica com a condição dos africanos até, pelo menos, as obras de Luís de Molina (1535 - 1600) e Alonso de Sandoval (1576 - 1652), ponto evidentemente diferente do ocorrido com a figura do índio, que foi desde cedo subordinada aos projetos dos jesuítas e alvo de uma discussão que relevava sua fraqueza de convicção religiosa. Se o processo de aldeamento na colônia constituiu, também, uma forma de convertê-los pela força do trabalho sob os olhos dos religiosos (ZERON, 2011), aos negros africanos, o trabalho forçado configurou uma constante mais dura, apoiada na lógica comercial do tráfico e sujeita às demandas dos senhores.

\footnotetext{
47 Apesar de versarem, na quase totalidade dos casos, sobre o problema em torno da escravização dos indígenas, alguns desses homens, como Bartolomé de Las Casas, Domingos de Soto e, principalmente, mais tarde, Alonso de Sandoval, dedicaram algumas páginas sobre o comércio de escravos da África e o problema de salvação de suas almas. Para exemplificar, Las Casas denunciava: "pelo que mostrava, dizem que fazia essas navegações no zelo de servir a Deus e levar os infiéis ao seu conhecimento ( ainda que não respeitasse os devidos meios), porém tenho eu como certo que mais ofendia a Deus do que o servia, porque infamava a sua fé e punha na aversão daqueles infiéis a religião cristã; e por uma alma que aceitasse a fé, a seu parecer, que porventura só por medo e força recebia o baptismo, ante todas as coisas lançavam os portugueses para os infernos muitas almas" (LAS CASAS, 1996, p. 319).

${ }^{48}$ Sobre o tema, ver também: PIMENTEL, Maria do Rosário. Viagem ao fundo das consciências: a escravatura na época moderna. Lisboa: Edições Colibri, 1995.

49 O célebre artigo do historiador Giuseppe Marccoci mostra, através de uma análise de história conectada, o peso da conversão na formação da sociedade portuguesa. Dessa forma, aponta a imagem de vil abandono da alma dos escravos negros africanos (MARCOCCl, 2010).
}

REHR | Dourados, MS | v. 13 | n. 25 | p. 55-75 | Jan. / Jun. 2019 


\section{HISTÓRIA}

\section{MUNDO LUSO BRASILEIRO: RELAÇÕES DE PODER E RELIGIÃO}

De qualquer forma, em decorrência da crença de que os africanos apresentavam uma predisposição mais evidente para a vida cristã, além das necessidades materiais e econômicas, estes não foram objetos, por conseguinte, de um movimento teológico-jurídico corpulento que reivindicasse as condições da sua subjugação ou questionasse os aspectos da sua conversão. Entregues aos mandos e desmandos dos senhores, foi, apenas, com maior vulto no século XVIII, principalmente no Brasil, que alguns padres se empenharam na escrita de tratados e manuais sobre o correto tratamento dos cativos, inclusive na regulação das suas crenças (MARQUESE, 2004). Esta mesma atitude dessemelhante perante dois tipos sociais submetidos na hierarquia da sociedade parece ser visível também na postura assumida pelo Tribunal da Fé. Ainda no século XVI, em 1579, uma provisão remetida pelo então inquisidor-geral, D. Jorge de Almeida, que atuou entre os anos de 1579 e 1586, ordenava ao Bispo da Bahia a inspeção sobre a heresia dos índios convertidos, com a ressalva de que não agissem rigorosamente "para que se não intimidassem os outros" (Apud MARCOCCI, 2013, p.116). Se parecia, nesse caso, haver um incentivo de adaptação do Santo Ofício às novas realidades e aos novos cristãos da América, os africanos não receberam, ao que parece, um tipo de olhar específico direcionado pelo Conselho Geral ou pelos membros centrais da instituição, muito embora, estes homens e mulheres, tenham, de fato, sido denunciados e processados na Mesa do Tribunal, por diferentes motivos.

$\mathrm{Na}$ análise dos processos, é possível perceber, assim, alguns elementos que delimitavam a importância do batismo e do conhecimento da doutrina. Na sessão de genealogia, que configurava uma das fases do interrogatório processual, toda a história de vida cristã do acusado devia ser apurada. Tal questionamento, que era norma central de atuação do Tribunal, vinha previsto e assegurado nos regimentos oficiais da instituição:

será perguntado [...] se é cristão batizado, e crismado, onde e por quem o foi, e quem foram seus padrinhos; e se depois que chegou aos anos de discrição, ia às igrejas; se ouvia missa, e se confessava, e comungava, e fazias as mais obras de cristão. Mandarão ao preso que se ponha de joelhos, e que se benza, e diga a doutrina cristã, a saber, o Padre Nosso, Ave Maria, Credo, Salve Rainha, mandamentos da lei de Deus e da Santa Madre Igreja (Regimento do Santo Ofício da Inquisição de 1640, p. 776). 


\section{HISTOORIA \\ MUNDO LUSO BRASILEIRO: RELAÇÕES DE PODER E RELIGIÃO}

A inspeção sobre o conhecimento da doutrina, que constituía os mesmos saberes indicados no ensino proposto pelo Padre Manuel Ribeiro Rocha (?-1778), demonstrava, muitas vezes, o "saber mal" dos cativos. O escravo Simão, por exemplo, acusado na Mesa do Santo Ofício em 1689, declarava, no decorrer do processo, que tinha sido batizado em Angola, mas que, ainda assim, não era crismado. Disse que sua doutrinação foi empenhada depois da sua chegada na Bahia, lugar, também, de onde iniciara sua acusação, e que fazia as mais obras de cristão, confessava e comungava. Posto de joelhos, de todo modo, soube rezar, diante dos inquisidores, a oração do Padre Nosso e Ave Maria, mas "o Creio em Deus pai soube mal, não soube Salve Rainha, nem os Mandamentos da Lei de Deus, nem os da Santa Madre Igreja" (AN/TT, TSO, IL, proc. 8464, f. 2). Se foi dada sua absolvição depois de uma reviravolta no processo, não houve, declaradamente, nenhuma consideração sobre o grau da sua instrução ou sobre sua condição de convertido. De forma semelhante, Jacques Viegas, denunciado pelo porte de bolsa de mandinga ${ }^{50}$ e pacto com o Demônio, não teve, na declaração de sua sentença, nenhum tipo de menção específica sobre a sua condição, embora, de forma parecida, também tenha demonstrado saber de forma incompleta os mandamentos e prédicas. Pelo contrário, em 1704, sob a jurisdição do tribunal de Lisboa, foi posto sob tormento e, posteriormente, condenado ao açoite, degredo e instrução ordinária. Antes, todavia, acentuava-se no auto, em consonância com a exigência da práxis, o porquê de sua pena e a sua obrigação de cristão: "que sendo o réu batizado e como tal obrigado a ter e crer tudo o que tem crê e ensina a Santa Madre Igreja de Roma [...], ele fazia o contrário" (AN/TT, TSO, IL, proc. 2355, f. 30).

O batismo, assim, configurou pré-requisito indispensável para a ação do Santo Ofício como um Tribunal de Fé. Como vínculo sacramental de pertença ao corpo cristão, à Inquisição não importava discutir as maneiras pelas quais o rito era ministrado, mas sim vigiar e controlar as consciências daqueles que, uma vez batizados, respondiam pelas suas culpas de convertidos (PROSPERI, 2010). No dia a dia da prática processual, a partir dos processos contra os escravos africanos, do

\footnotetext{
50 A expressão "bolsa de mandinga" foi cunhada pelos religiosos que missionavam na África; já "patuá" era genericamente usada para designar variados tipos de amuletos. Ambas as expressões, ao serem conhecidas no Império português, ganharam a significação de feitiços próprios dos africanos (SANTOS, 2008).
}

REHR | Dourados, MS | v. 13 | n. 25 | p. 55-75 | Jan. / Jun. 2019 


\section{HISTÓRIA \\ MUNDO LUSO BRASILEIRO: RELAÇÕES DE PODER E RELIGIÃO}

reino ou colônia, é possível perceber que, via de regra, mais valia a consideração sobre a qualidade da culpa (pacto diabólico, sodomia etc) do que sobre a condição de recém convertido e/ou "ignorante" do acusado. ${ }^{51} \mathrm{O}$ cuidado com o ensinamento dos cativos na fé, que recaía sobre os senhores, pode ser visto, aqui, como uma função primordial para a devida ação do Santo Ofício. Se os inquisidores, focados em controlar a heresia dos judaizantes, adaptaram-se, com a experiência ultramarina, a outros tipos de comportamentos heréticos e a novos tipos de cristãos, os senhores se empenharam na denúncia dos seus escravos mais em decorrência das adversidades do cotidiano, contendas e temores, do que da obrigação imposta pela religião.

\section{Castigo e medo}

Em um universo habituado com os elementos mágicos, muitos estiveram no âmago da relação complexa entre escravos e senhores. Entre os processos do tribunal de Lisboa, não foi incomum encontrar relatos de cativos que diziam empenhar diversas práticas, protetivas ou de ataque, como resposta ao comportamento severo de seus donos e aos castigos recebidos. Muitos desses conhecimentos, advindos de África e aprendidos através do contato com os semelhantes (SWEET, 2007), transformaram-se, na realidade do cativeiro, em mecanismos de sobrevivência. Não constituíam, ao que parece, práticas claras de sublevação, mas sim costumes mais banais que, uma vez empenhados pelos escravos, faziam deles os protagonistas no âmbito de uma relação cujos senhores, na maior parte das vezes, detinham o controle e o mando. Estes, por outro lado, não hesitaram em empreender denúncias na Mesa do Santo Ofício contra aqueles que consideravam, no mais alto grau de subserviência, suas propriedades.

"Tratar com aspereza" ou "dar muitas pancadas" configuraram, nesse contexto, argumentos repetitivos empregados pelos cativos no momento das

\footnotetext{
51 Isto não significa, no entanto, que não exista casos em que os escravos foram vistos sob o atenuante de recém convertidos ou "ignorantes" e, dessa maneira, recebidos com uma certa clemência. Esta análise está sendo desenvolvida, de forma específica, no âmbito da minha tese de doutorado e poderá ser, a partir de um conjunto maior de fontes, melhor abordada posteriormente.
}

REHR | Dourados, MS | v. 13 | n. 25 | p. 55-75 | Jan. / Jun. 2019 


\section{HISTÓRIA}

\section{MUNDO LUSO BRASILEIRO: RELAÇÕES DE PODER E RELIGIÃO}

inquirições, enquanto, para os senhores, as denúncias eram baseadas na ideia de que existia, entre os homens e, principalmente, as mulheres africanas, um hábito comprovado de manejar malefícios. Essa prática, entendida como a vertente mais nociva do feitiço, com a função específica de fazer algum mal efetivo a uma pessoa ou propriedade (PAIVA, 2002), causou, dentro dessa relação, o sentimento de desconfiança e medo. Os inquisidores, ao inquirirem aqueles que, a partir da apresentação, tornavam-se réus, sempre agiam no sentido de descobrirem um pretenso pacto diabólico, objetivo obstinado do Tribunal do Santo Ofício sobre os casos que envolviam práticas mágicas, principalmente quando em relação aos africanos (LAHON, 2004).

Nesse sentido, Florinda Maria de São José, escrava de D. Teresa de Jesus e Sousa, confessou, em 1736, ter realizado um tipo de feitiço que deixou sua senhora gravemente enferma. Além de encomendar um boneco de trapos para alfinetar, com o objetivo de causar dores, a escrava também "deu peçonha em uma sopa de vaca" para a senhora comer. A ação passava pela assertiva de que "ela guardava uma grande raiva da dita sua senhora por dar-lhe muitas pancadas", tipo de motivo que se mostrou constante nas "defesas pessoais" dos escravos perante os inquisidores (AN/TT, TSO, IL, proc. 437, f.11). Se, por um lado, os senhores pareciam buscar a Inquisição em decorrência do ambiente de temor e desconfiança, os escravos, quando interrogados, demonstravam a vivência extrema em que estavam submetidos.

O castigo, que era, além de um simples instrumento de correção diária, um direito e, até mesmo, uma obrigação senhorial, tornou-se, no âmbito das histórias relatadas nos processos da Inquisição, o principal motivo de desamores entre os diferentes partícipes do cativeiro. Durante todo o período colonial, com efeito, as leis, que foram baseadas prioritariamente nas Ordenações do Reino (1603), deixavam um grande espaço de determinação aos senhores sobre os corpos dos seus escravos (GRINBERG, 2018). A falta de moderação, assim, como demonstraram diferentes padres, por exemplo, André João Antonil (1649 - 1716), Jorge Benci (1650 - 1708) e o já citado Manuel Ribeiro Rocha (? - 1778), era danosa ao

sucesso da dominação senhorial, já que poderia resultar, e de fato resultou, no dano físico do escravo ou na sua insubordinação (representada nas fugas, suicídios 


\section{HISTÓRIA}

\section{MUNDO LUSO BRASILEIRO: RELAÇÕES DE PODER E RELIGIÃO}

e práticas cotidianas de retaliação), ambos resultados adversos causados por práticas que, embora não fossem as únicas, acabaram por tornarem-se as mais comuns no controle cotidiano da escravaria.

A escrava Paschoa, por exemplo, denunciada, primeiramente, na justiça eclesiástica da capitania de São Paulo, em 1749, foi, depois da apuração das culpas, transferida à jurisdição inquisitorial. Acusada de causar malefícios e a morte de vários membros da família que a possuía, a ação de Paschoa era instigada pela raiva que ela sentia da sua senhora, já que, de forma semelhante, esta "Ihe dava muitas pancadas". No processo, a escrava admitia a culpa e reiterava sua convicção: "enquanto não matasse sua senhora, não havia de desistir da empresa começada" (ACMS ${ }^{52}$, Processo da escrava Paschoa, 1749). Em outro exemplo extremo, Catarina Maria, escrava do Beneficiado José de Machado, em Lisboa, foi denunciada pelo crime de feitiçaria. Com um histórico de conflitos com seus senhores, Catarina confessou, em 1733, ter pacto com o Demônio e, com a ajuda dele, manipular feitiços para padecerem e adoecerem seus donos. Entre as práticas declaradas, dizia que, por meio de palavras aprendidas em Angola, de onde era natural, poderia, quando quisesse, aplicar os males e doenças, assim como também detinha o poder de proferir palavras para curá-las; mais efetivamente, confessava que colocava "baba nos caldos preparados" e praticava outras travessuras (AN/TT, TSO, IL, proc. 6286, f. 9). O castigo, nesses casos específicos, embora sempre presente, como consta nos autos, não apresentava um resultado de controle, mas, pelo contrário, fomentava a retaliação.

Como visto, o pacto com o Demônio se transformou, também, em uma forma de auxílio. Entendido como uma troca, a efetivação do acordo, por meio do sangue e outros elementos, sempre exigia do escravo algum tipo de ação compensadora. No mais, em diversos relatos, o Diabo exigia, como condição para o auxílio, a entrega do corpo e alma do pactuante (BETHENCOURT, 2004). Isso significava o afastamento das coisas de Deus ou, no caso de seres que viviam tutelados, a dissimulação acerca da crença católica. Sem efetivar o pacto com o Diabo em si, Marcelina Maria confessava, no entanto, tê-lo invocado. Essa prática, declarada por meio da demonstração do seu desespero com as punições e correções diárias, tinha

52 Arquivo da Cúria Metropolitana de São Paulo.

REHR | Dourados, MS | v. 13 | n. 25 | p. 55-75 | Jan. / Jun. 2019 


\section{HISTÓRIA \\ MUNDO LUSO BRASILEIRO: RELAÇÕES DE PODER E RELIGIÃO}

por função, no caso de Marcelina, implorar a ajuda com os abusos diários. Com tal auxílio, então, conseguiu, dentre outras tarefas, amassar e levedar o pão rapidamente, o que, conforme sua própria crença, "só por arte do Demônio se podia fazer tão depressa". A vida de Marcelina, até então atribuída unicamente aos ditames dos seus senhores, depois de transferida ao Santo Ofício, conheceu um novo tipo de imposição, agora proeminentemente colocada sobre a sua consciência. Conforme a confissão, a escrava, dividida entre culpa e retaliação, expunha a condição de sua vida cativa:

Disse mais que tornando para a casa do seu senhor, no mês de Abril passado, ele a tratou com aspereza e lhe tornou a vir o aborrecimento à escravidão naquela casa, e haverá três semanas, por ter notícia, o mesmo seu Senhor, que ela andava amancebada com um preto da casa, a mandou despir nua, atando-lhe as mãos, pegando nela um preto e outro açoitando e o mais sensível para ela foi ver-se descomposta diante de seis ou sete homens, sendo um deles o dito seu senhor e seu filho mais velho [...]. Disse que ela, ainda muito desesperada e com o desejo grande de o demônio the aparecer e a ajudar no serviço daquela casa, muito bem conhecia e entendia que se se entregava ao demônio ia para o inferno e perdia a sua alma. [...]. Disse que ela chamou o demônio provocada pela sua desesperação e naquele repente da sua paixão não assentou em tal coisa e lhe parece que nem alma nem corpo lhe entregaria (ANTT, TSO, IL, proc. 631 , f. 6 ).

Os tipos de feitiços usados variavam entre as intenções de causar algum tipo de dano aos senhores, mas também proteger-se da sua ira; chamar a atenção da casa senhorial, bem como tentar ser vendido e mudar de proprietário (MELLO, 1992). No ambiente cotidiano, não faltava espaço para os desafetos, mas também se remediava com a negociação (REIS; SILVA, 1989). A vivência, dessa maneira, não se baseou apenas no castigo dos senhores e no revide dos escravos; de uma outra forma, ambos se coadunaram, trocaram papéis e mantiveram uma certa dependência. Esse tipo de contato também chegou ao Santo Ofício, que preocupado com a heresia, introduziu-se, igualmente, nas formas de harmonia presentes no cativeiro.

O caso da escrava Rosa Egipcíaca é exemplar nesse sentido. Foi presa pelo Santo Ofício, mas não foi sozinha, levou consigo o seu último proprietário, o padre Francisco Gonçalves Lopes. A cativa, encarcerada em 1762, no Rio de Janeiro, teve 


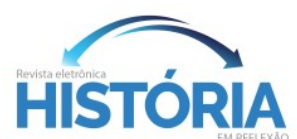

\section{MUNDO LUSO BRASILEIRO: RELAÇÕES DE PODER E RELIGIÃO}

uma vida nada ordinária, apontada em diferentes denúncias enviadas, posteriormente, à Mesa do Santo Ofício de Lisboa, para o qual foi remetida, em 1763. Acusada de heresia formal por falsa santidade e falsas virtudes, o primeiro encontro com o padre aconteceu a partir da necessidade dele lhe fazer um exorcismo. Depois disso, o contato se tornou maior: padre Francisco foi seu primeiro devoto, confessor e, mais tarde, Ihe daria a alforria. As denúncias demonstravam sua crença na predestinação da escrava, mas essa convicção, no entanto, não perdurou sob o julgamento da Inquisição, momento em que o bom contato entre ambos foi renegado pelo religioso (MOTT, 1993).

As práticas mágicas, assim, que poderiam indicar, ainda, curandeirismos ou outras ações dos africanos, estiveram no meio da relação complexa entre senhores e escravos. Outros costumes, crenças e hábitos, no entanto, que serão, em outro momento, objetos de estudo, também foram motivos de contendas ou relacionamentos, como os casos de sodomia, bigamia, islamismo etc. É possível considerar, de todo modo, que, embora os senhores tivessem sob as suas responsabilidades a salvação das almas dos cativos e, nesse sentido, a permissividade do erro também os transformavam em transgressores, a exigência de cristão não configurou um motivo suficiente para os levar as denúncias ao Santo Ofício contra os seus próprios escravos. Como visto, aspectos das relações, muitas vezes tidos como conflituosos, formaram o mote principal que fomentava nos senhores a entrega de seus cativos aos inquisidores, mesmo que isso significasse, em termos econômicos, a perda material de uma propriedade e uma força a menos no trabalho extenuante do dia a dia do cativeiro.

Considerações finais

No centro do nascimento do Império, esteve, também, a missão de fazer prevalecer e expandir a Santa Fé Católica. Como braço importante para a segurança dessa ortodoxia, nasceu e cresceu o Tribunal da Fé, o Santo Ofício da Inquisição, vigilante contra a desobediência e o intento de escolha pessoal dos cristãos. De início, com o olhar voltado aos hereges judaizantes, que eram vistos como ameaça oficial à sociedade e ao êxito da Coroa, o Santo Ofício aprendeu, posteriormente, a partir da experiência expansionista, a adaptar-se aos novos tipos de cristãos e aos seus erros. Em África, especialmente, a maior preocupação se voltou às práticas 


\section{HISTÓRIA \\ MUNDO LUSO BRASILEIRO: RELAÇÕES DE PODER E RELIGIÃO}

religiosas dos habitantes convertidos, entendidas, sob o olhar incriminador dos inquisidores, como feitiçarias e pacto com o Diabo. Esses homens e mulheres, espalhados, compulsoriamente, aos confins do Império, estiveram, no reino ou na colônia, sob a competência dos inquisidores. Essas vidas recém convertidas foram, de qualquer forma, alvos de um projeto com um objetivo grande: extirpar toda a heresia e apostasia daqueles que foram, então, "feitos cristãos".

O intuito deste texto foi, assim, o de demonstrar as premissas importantes que constituíram o batismo e a instrução na fé, bem como o debate jurídico-teológico que as cercaram, para apontar a atuação daquele que foi entendido como a ponta final da vigilância sobre as consciências, o Tribunal da Inquisição. Imbuída desse objetivo, foi possível, também, demonstrar o lugar atribuído aos senhores na efetivação do batismo e no empenho com a correta instrução da doutrina, premissas importantes para a aplicação das correções e das penas. A partir do olhar sobre a relação entre senhores e escravos, a análise demonstrou que, mais do que incentivados pelo cuidado com a salvação dos cativos, os senhores os denunciaram devido aos medos, contendas e conflitos do cotidiano. Do ponto de vista dos escravos, que foram feitos cativos e convertidos, amiúde, à força, suas vidas e vivências estiveram, em diferentes momentos, sob a autoridade de dois poderes: dos senhores aos inquisidores. Para eles, como brevemente demonstrado, as práticas, aprendidas em África ou compartilhadas com os semelhantes, transformavam-se em mecanismos possíveis de defesa e sobrevivência.

\section{Referências Bibliográficas}

\section{Fontes}

Arquivo Nacional da Torre do Tombo

AN/TT, TSO, IL, proc. 6286.

AN/TT, TSO, IL, proc. 437.

AN/TT, TSO, IL, proc. 2355.

AN/TT, TSO, IL, proc. 631.

AN/TT, TSO, IL, proc. 8464.

AN/TT, TSO, IL, Cadernos do Promotor, n. 86, livro 279.

AN/TT, Conselho Geral do Santo Ofício, livro 272. 


\section{HISTÓRIA}

MUNDO LUSO BRASILEIRO: RELAÇÕES DE PODER E RELIGIÃO

Arquivo da Cúria Metropolitana de São Paulo

ACMS, Processo da escrava Paschoa, 1749.

Instituto Histórico e Geográfico Brasileiro

Regimento do Santo Ofício da Inquisição dos Reinos de Portugal ordenado por mandado do ilustríssimo e reverendíssimo senhor Bispo, dom Francisco de Castro, Inquisidor Geral do Conselho de Estado de Sua Majestade - 1640. Revista do Instituto Histórico e Geográfico Brasileiro. Rio de Janeiro: Instituto Histórico e Geográfico Brasileiro, a. 157, n. 392, jul./set., 1996.

Outras fontes

BLUTEAU, Raphael. Diccionario da língua portuguesa composto pelo padre Rafael Bluteau, reformado, e acrescentado por Antonio de Moraes Silva. Tomo Segundo (L-Z). Lisboa: Na Officina de Simão Thaddeo Ferreira, 1789.

Ordenações Filipinas: Livro V. Organização de Silvia Hunold Lara. São Paulo: Companhia das Letras, 1999.

Ordenações do Senhor Rey D. Manuel. Coimbra: Na Real Imprensa da Universidade, 1797.

LAS CASAS, Pe. Bartolomé de. Brevíssima relação da destruição de África: prelúdio da destruição das índias. Primeira defesa dos guanches e dos negros contra a sua escravização. Estudo preliminar de Isácio Pérez Fernández. Lisboa: Edições Antígona, 1996.

ROCHA, Pe. Manuel Ribeiro. Etíope resgatado, empenhado, sustentado, corrigido, instruído e libertado. Edição preparada, introduzida e comentada por Jean Marcel Carvalho França e Ricardo Alexandre Ferreira. 1. Ed. São Paulo: Editora Unesp, 2017.

VIEIRA, Pe. António. A Chave dos Profetas: livros primeiro, segundo e terceiro. Direção de José Eduardo Franco e Pedro Calafate. Tradução do latim de António Guimarães Pinto. 1. Ed. Lisboa: Temas e Debates, 2015.

ZURARA, Gomes Eanes de. Crónica do descobrimento e conquista da Guiné: segundo o manuscrito da Biblioteca Nacional de Paris. Modernizada, com notas, glossário e uma introdução de José de Bragança. Textos de história, n.3. Porto: A Portuense, 1937. 


\section{HISTÓRIA \\ MUNDO LUSO BRASILEIRO: RELAÇÕES DE PODER E RELIGIÃO}

Estudos

ALMEIDA, Carlos. "Habitantes desta negra Etópia, descendentes de Ham": a maldição de Ham na literatura missionária sobre a região centro-ocidental do continente africano (sécs. XVI-XVII). Estudos Ibero-americanos, Porto Alegre, v.44. n.3, pp .409-420, 2018.

BETHENCOURT, Francisco. História das Inquisições: Portugal, Espanha e Itália (séculos XV - XIX). São Paulo: Companhia das Letras, 2000.

O imaginário da magia: feiticeiras, adivinhos e

curandeiros em Portugal no século XVI. São Paulo: Companhia das Letras, 2004.

CISNEROS, Gerardo L. Ignorancia invencible? Superstición e idolatria ante el Provisorato de índios y chinos del Arzobispado de México em el siglo XVIII. México: Universidad Nacional Autónoma de México, 2014.

FOUCAULT, Michel. O que é um autor? Tradução de António Fernando Cascais. Lisboa: Passagens, 2018.

FEITLER, Bruno. Teoria e prática na definição da jurisdição e da práxis inquisitorial portuguesa: da 'prova' como objeto de análise. In: ALGRANTI, Leila Mezan; MEGIANI, Ana Paula Torres. (org.). O Império por escrito: formas de transmissão da cultura letrada no mundo ibérico (séc. XVI - XIX). - São Paulo: Alameda, 2009.

FURTADO, Júnia Ferreira; RESENDE, Maria L. C. de. (org.). Travessias inquisitoriais das Minas Gerais aos cárceres do Santo Ofício: diálogos e trânsitos religiosos no Império luso-brasileiro (séculos XVI-XVIII). 1. Ed. Belo Horizonte: Fino Traço, 2013.

GRINBERG, Keila. Castigos físicos e legislação. In: SCHWARCZ, Lilian; GOMES, Flávio. (orgs.). Dicionário da escravidão e liberdade: 50 textos críticos. 1. Ed. São Paulo: Companhia das Letras, 2018.

HORTA, José. A representação do africano na literatura de viagens: do Senegal à Serra Leoa (1453 - 1508). Mare Liberum, n. 2, 1991.

. A Inquisição em Angola e Congo: o inquérito de 1596-98 e o papel mediador das justiças locais. História e Crítica. Lisboa, vol.2, 1988.

LAHON, Didier. Inquisição, pacto com o demônio e "magia" africana em Lisboa no século XVIII. Topoi, v. 5, n.8 2004, pp. 9 -70.

MARCOCCI, Giuseppe. A consciência de um Império: Portugal e o seu mundo (séculos XV - XVII). Coimbra: Imprensa da Universidade de Coimbra, 2012. Escravos ameríndios e negros africanos: uma história conectada. Teorias e métodos de discriminação no Império português (ca 1450 1650). Revista Tempo, n. 30, 2010. 


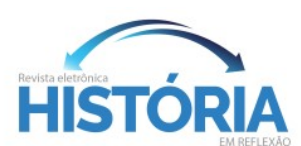

\section{MUNDO LUSO BRASILEIRO: RELAÇÕES DE PODER E RELIGIÃO}

MARQUESE, Rafael de B. Feitores do corpo, missionários da mente: senhores, letrados e o controle dos escravos nas Américas, 1660-1860. São Paulo: Companhia das Letras, 2004.

MARCOCCI, Giuseppe; PAIVA, José Pedro. História da Inquisição portuguesa (1536 - 1821). Lisboa: A Esfera dos Livros, 2013.

MELLO, Evaldo Cabral de. Como manipular a Inquisição para mudar de senhor. Revista Novos Estudos - CEBRAP. N. 33. São Paulo, 1992. pp. 115 - 127.

MOTT, Luiz. Rosa Egipcíaca: uma Santa Africana no Brasil. Rio de Janeiro: Editora Bertrand Brasil, 1993.

PAIVA, Eduardo F. Dar nome ao novo: uma história lexical da Ibero-América entre os séculos XVI e XVIII (as dinâmicas de mestiçagens e o mundo do trabalho). 1. Ed. Belo Horizonte: Autêntica Editora, 2015.

PAIVA, José Pedro. Bruxaria e superstição num país sem caça às bruxas (16001774). 2. Ed. Lisboa: Editorial Notícias, 2002.

PEREIRA, Ana Margarida S. Inquisição e Escravidão: reflexões em torno do Brasil colonial (Rio de Janeiro, séculos XVII - XVIII). Plurais: Revista Multidisciplinar da UNEB, v. 5, pp. 12 -29, 2014.

PIMENTEL, Maria do Rosário. Viagem ao fundo das consciências: a escravatura na época moderna. Lisboa: Edições Colibri, 1995.

PROSPERI, Adriano. Tribunais da Consciência: inquisidores, confessores, missionários. Tradução de Homero Freitas de Andrade. São Paulo: EDUSP, 2013. Dizionario storico dell'Inquisizione. Vols. I, II e III. Pisa:

Edizioni della Normale, 2010.

REIS, João José; SILVA, Eduardo. Negociação e conflito: a resistência negra no Brasil escravista. São Paulo: Companhia das Letras, 1989.

SAUNDERS, A. C. de C. M. História social dos escravos e libertos negros em Portugal (1441 - 1555). Lisboa: Imprensa Nacional - Casa da Moeda, 1994.

SANTOS, Vanicléia S. As bolsas de mandinga no espaço atlântico: século XVIII. (Tese de doutorado). São Paulo: Universidade de São Paulo, 2008.

SILVA, Filipa Ribeiro da. A Inquisição em Cabo Verde e S. Tomé e Príncipe (1536 a 1821): contributo para o estudo da política do Santo Ofício nos territórios africanos. (Dissertação de mestrado). Faculdade de Ciências Sociais e Humanas da Universidade Nova de Lisboa, 2002.

SWEET, James. Recriar África: cultura, parentesco e religião no mundo afro português (1441-1770). Lisboa: Edições 70, 2007 


\section{HISTÓRIA}

MUNDO LUSO BRASILEIRO: RELAÇÕES DE PODER E RELIGIÃO

THORTON, John. A África e os africanos na formação do mundo Atlântico (1400-1800). Tradução de Marisa Rocha Mota. Rio de Janeiro: Elsevier, 2004.

ZERON, Carlos Alberto de M. R. Linha de Fé: a Companhia de Jesus e a escravidão no processo de formação da sociedade colonial (Brasil, séculos XVI e XVII). São Paulo: EDUSP, 2011. 